\title{
Determinant Selection Motorcycle Effects Of Interest Product Design And Celebrity Endorser
}

\author{
Edi Setiawan ${ }^{1}$, Faizal Ridwan Zamzany $^{2}$, Sunarta $^{3}$ and Desi Azhari ${ }^{4}$ \\ \{ edisetiawan@uhamka.ac.i1', zamzany@uhamka.ac.id², sunarta@uhamka.ac.id ${ }^{3}$, \\ desiazhari@gmail.com ${ }^{4}$ \} \\ 1,2,3,4 Faculty of Economics and Business, University of Muhammadiyah Prof. DR. HAMKA, Jakarta, \\ Indonesia
}

\begin{abstract}
This study aims to determine the effect of product design and celebrity endorser on the interest in buying a Honda Motorcycle Beat Pop in Cikarang. The variables studied were product design and celebrity endorser as independent variables and buying interest as a dependent variable for consumers of Honda motorcycle Beat Pop in Cikarang. Population in this study is consumers of Honda Pop Beat in Cikarang. The number of samples was 99 respondents. The data is processed using multiple linear regression analysis. Sampling is done by accidental sample technique items, namely consumers in Cikarang. Based on the statistical analysis of the data, all indicators in this study are valid and also the variables are reliable. The results of this study state that product design and celebrity endorser together simultaneously have a positive effect on buying interest.
\end{abstract}

Keywords: Product Design, Celebrity Endorser, Buying Interest.

\section{Introduction}

In today's age, many changes in various aspects including how companies promote products and services. The number of new companies that have sprung up in multiple fields will affect the level of sales of a product. The phenomenon happens, the increasingly fierce market competition in the business world, then it implies that the company will be vying to survive and thrive in the marketplace. Companies are required to understand better the behaviors and needs of consumers in the market and of course to be able to cultivate interest in buying the product. (Ghoshal, S, 2005).

Today many motorcycle brands pop with various models, designs, providing excellent quality and the price is quite competitive.(Shocker, A. D., et al., 1994). For companies engaged in automotive, this is an opportunity for market share. Companies that want to excel in marketing a product should pay attention to consumer buying behavior. Consumer behavior is all the activities, actions, as well as the psychological processes that encourage efforts at the time before purchase, use, spend the following products and services to do things above or evaluate activity. (Wicaksono, M. A, 2018).

Buying interest is the tendency of consumers to buy something brand or take action related to the purchase of which is measured by the level of likelihood that consumers make purchases. Many ways in which the company's growing interest in consumer buying. (Park, D. H., Lee, J., \& Han, I., 2007). Examples such as by offering a variety of quality products, design a good product and also vary regarding product design and other benefits of the product, of course, accompanied by promotions and attractive example by using celebrities as characters promotion to provide interest buy on prospective customers. If the company is not able to transform and take advantage of market opportunities the company will inevitably be displaced by other companies (Listyawati, I. H., 2016). 
The product design is one formulated the appeal of a product. Designs can be formed to attribute to a product so that it can become the hallmark of the brand product. (Fionda, A. M, et al., 2009). If the company already understand consumer behavior, so the company can design what should be done to meet consumer desires. (Teece, D. J, 2010; Oliver, R. L, 1999). Companies must implement some interesting strategies not to give the consumer buying interest and retaining existing customers. Why is that, because of the design of the product is the first thing seen to get an impression of the consumer. (Crilly, N., Moultrie, J., et al., 2004). If it sees an attractive product will undoubtedly affect the consumers' desire to have it. In addition to product design is concerned, the promotion on television is also important and should be considered. (Padmantyo, S. et al., 2014).

Nowadays many things must be considered by companies when designing the creation, for example when determining the commercials that you want to use as an endorser as we know that endorser role important to a consumer buying interest. (Erdogan, B. Z, 1999). The use of celebrities as endorsers demand by manufacturers because of the message delivered by the source of interest, such celebrities that are popular and accomplished will receive greater attention and memorable. Celebrity selected should have a positive image and good in the eyes of the public so that more people like it. In general, a celebrity is a different matter because favored by many people and has an advantage compared with other individuals. Sometimes the charism contained in the self-celebrity and his words were well able to influence someone to direct his attention to the celebrity (Butar, D. K. M. B., et al., 2016).

Only celebrities in their field of expertise that is perceived to significantly impact respondents to be interested and ultimately purchase. In his research, Ohanian getting three factors that caused the respondents are willing to buy such as physical attractiveness (Beautiful, handsome, tall, white and so on) can be believed, and the latter because of their expertise (skills) endorser. (Sudarti, K, 2014).

Celebrity endorsers are one method that is most popular in the world, using celebrity draw, has high popularity and can be trusted by the public intended to make products that are promoted to be known, unknown and desirable. (McMullan, J. L., \& Miller, D, 2008). The use of celebrity supporters has to go through some considerations, including the level of popularity of celebrities chosen to represent the character of the products being advertised. Selection of celebrities that will be used cultivated by celebrities who have achievements, a good image for the community and do not have a problem. This is done because it aims to create an image of the company's products.

Lately a lot of competition motorcycle sales that have sprung up in various media including on TV ads by cooperating with various celebrities, such as singers, movie player and so on. Not to be outdone, Motorcycles Honda also took the artist famous girl group that has a lot of fans that JKT 48. Based on a survey conducted by one of the institutions that Yahoo OMG Awards in 2015 ago to measure the loyalty of fans to their idols musicians are far superior to the achievement JKT48 as many as 46167 voters or 51 percent. Here are the rankings of celebrities Indonesian with the most loyal fans:

Table 1. Celebrity Fans Rating Indonesia

\begin{tabular}{llll}
\hline No & $\begin{array}{l}\text { Celebrity } \\
\text { names }\end{array}$ & $\begin{array}{l}\text { Number } \\
\text { of Voters }\end{array}$ & Percent \\
\hline 1 & JKT48 & 46167 & 51 \\
\hline 2 & $\begin{array}{l}\text { Agnes } \\
\text { Monica }\end{array}$ & 23768 & 24 \\
\hline 3 & Slank & 10,594 & 12 \\
\hline
\end{tabular}




\begin{tabular}{llll}
\hline 4 & $\begin{array}{l}\text { Maia } \\
\text { Estianti }\end{array}$ & 5643 & 6 \\
\hline 5 & Afgan & 4062 & 5 \\
\hline
\end{tabular}

Source: www.aisi.co.id, 2018.

From the data above, we can see that the 48 is a celebrity who has the most fans in comparison to other celebrities. Popularity JKT48 utilized by the Honda to be a Celebrity Endorser Motorcycle Honda Beat Pop. Honda company hopes that JKT48 in promoting its products can increase consumer buying interest and also increase the number of motorcycle sales this

Honda Pop Beat was launched by PT Astra Honda motorcycle at the end of 2014. PT. Astra Honda introduced to the public by using the television advertising by cooperating JKT48 as the endorser. Based Barnas.com Daily explained that motorcycle is magic Beat is the best-selling to date. Not only in Indonesian but also in many countries of motorcycles Honda beat was established itself as the world's best-selling scooter magic. Here is a motorcycle sales data by the Indonesian Motorcycle Industry Association (AISI) throughout 2017:

Table 2. Bicycle Motor Sales Data 2017

\begin{tabular}{ll}
\hline Brand Motor & 2017 \\
\hline Honda Beat & 1959263 \\
\hline $\begin{array}{l}\text { Honda Vario } \\
\text { series }\end{array}$ & 1200287 \\
\hline Scoopy & 612109 \\
\hline Yamaha Mio & 282097 \\
\hline Yamaha Nmax & 152479 \\
\hline Honda Revo & 150582 \\
\hline
\end{tabular}

Source: www.aisi.co.id, 2018.

Based on sales data from the Indonesian Motorcycle Industry Association (AISI) above we can see that compared with other motorcycle brands, Honda Beat is the best selling motorcycle throughout 2017 with as many as 1,959,263 units distributed or dredge means a market share of $33 \%$,

\section{Research Methods}

The research is research using survey method. Based on the title of the thesis that has been said above, namely: "The Effect of Product Design and Celebrity Endorser of the Interests Buy Honda Beat Pop in Cikarang." Then the variables studied can be divided into two independent variables X1 is a Product Design, and X2 is Celebrity Endorser, and Interests Buy dependent variable (Y).

The population in this study is that consumers of Honda Beat Pop in Cikarang. These samples are used with accidental sampling method and using the formula slovin. The number of samples in this study was as many as 99 responded. Technic collecting data in this study is to use a questionnaire which refers to the measurement of the Likert scale.

Validity test used to measure invalid or not a questionnaire. If the person who obtained the correlation coefficient significance level below 0.05 means that the data obtained are valid, reliability tests performed jointly on all questions. If the alpha value $>0.60$, are called reliable. 
Given the analysis method used is multiple linear regression analysis and research data used are primary and secondary data, so to meet the requirements set so that the use of multiple linear regression testing needs to be done on some of the assumptions of classically used for this research that such normality test, multicollinearity, and heteroscedasticity test.

The statistical test t partially used to test each variable. Results test can be seen in the table on the column sig coefficients (significance). If the $t$ value or significance probability $<0.05$, it can be said that there is the influence of independent variables on the dependent variable partially. However, if the probability value or significance $t>0.05$, it can be said that there is no significant influence of each independent variable on the dependent variable (Ghozali, 2013).

$\mathrm{F}$ statistical test is basically whether all the variables $\mathrm{X} 1$ (product design) and $\mathrm{X} 2$ (celebrity endorser) in the model have jointly influence to variable Y (buying interest). USING SPSS 23 as a measure to determine the test results of the test statistic $\mathrm{f}$ with a significance level of $0.05(\alpha=5 \%)$.

\section{Discussion And Results}

Based on the results of a study of 99 respondents who are consumers of Honda Beat Pop in Cikarang. Based on the test data validity of the instrument of variable product design, celebrity endorser on buying interest from all points shows that the statement is valid, it is because $r$ count $>r$ table and all the variables declared reliable because $r$ alpha $>0.60$.

And these values can be explained that the constant of 1,062, if the design of products and Celebrity Endorser is 0, then the purchase interest in value by 1,062. Coefisien regression of 0.457 product design, if the design of the product has increased one unit, then buying interest will increase amounted to 0.457 units assuming the other independent variable regression fix. Coefisien celebrity endorser of 0.278 , if Celebrity endorser increased one unit, then buying interest will increase by 0.278 units assuming the other independent variables remain valuable.

Table 3. Coefficients

\begin{tabular}{|c|c|c|c|c|c|c|c|c|}
\hline \multicolumn{9}{|c|}{ Coefficients $^{\mathrm{a}}$} \\
\hline \multirow{2}{*}{\multicolumn{2}{|c|}{ Model }} & \multicolumn{2}{|c|}{$\begin{array}{l}\text { Unstandardized } \\
\text { Coefficients }\end{array}$} & \multirow{2}{*}{$\begin{array}{l}\text { Standardize } \\
\text { d } \\
\text { Coefficients } \\
\text { Beta }\end{array}$} & \multirow[t]{2}{*}{$\mathrm{T}$} & \multirow[t]{2}{*}{ Sig. } & \multicolumn{2}{|c|}{$\begin{array}{l}\text { Collinearity } \\
\text { Statistics }\end{array}$} \\
\hline & & B & $\begin{array}{l}\text { Std. } \\
\text { Error }\end{array}$ & & & & $\begin{array}{l}\text { Toleranc } \\
\mathrm{e}\end{array}$ & VIF \\
\hline \multirow[t]{3}{*}{1} & $\begin{array}{l}\text { (Constant } \\
\text { ) }\end{array}$ & $\begin{array}{l}1,06 \\
2\end{array}$ & ,184 & & $\begin{array}{l}5,75 \\
9\end{array}$ & ,000 & & \\
\hline & $\begin{array}{l}\text { Product } \\
\text { Design }\end{array}$ & ,457 & ,046 &, 596 & $\begin{array}{l}9,84 \\
4\end{array}$ & ,000 & ,868 & $\begin{array}{l}1,15 \\
2\end{array}$ \\
\hline & $\begin{array}{l}\text { Celebrity } \\
\text { endorser }\end{array}$ & ,278 & ,042 & ,405 & $\begin{array}{l}6,68 \\
9\end{array}$ & ,000 & ,868 & $\begin{array}{l}1,15 \\
2\end{array}$ \\
\hline
\end{tabular}

a. Dependent Variable: RATA MB

Source: Results Output

Based on the table above shows that the partial design of the product has a positive and significant impact on buying interest. And partially celebrity endorser has a positive and significant influence on buying interest. 
Based on SPSS output seen that X1 (product design), X2 (celebrity endorser) and Y (buying interest) has a value F Count 109.152 > F 0:05 $(2: 96)=\mathrm{F}$ table of $3.09(\mathrm{df}=$ no-1) or $(96=99-2-1)$. Also, the results of sig $0.000<0.05$. Then by the hypothesis that the $\mathrm{H}^{3}$ that $\mathrm{X} 1$ (product design) and $\mathrm{X} 2$ (celebrity endorser) effect together (simultaneously) to $\mathrm{Y}$ (buying interest).

\section{Conclusion}

Based on the results of the discussion of the previous chapter, it can be concluded that based on table it can be concluded that the calculation of the average value indicator product design can be said to be "Pretty Good", is said to be good enough for the design of a product is a part that was first seen by a consumer engaging or not, The calculation of the average value of the indicator celebrity endorser through the interpretation of value can be said to be "Pretty Good", is said to be good enough for celebrity endorser is part of the reason or consideration for consumers before buying a Honda Beat motorcycle Pop. Based on the calculation of the average indicator value buying interest $(\mathrm{Y})$ through the interpretation it can be said "Pretty Good" because buying interest is consumer interest to buy Honda motorcycle products Beat Pop. Based on the results of SPSS output can be seen that the variable product design positively affects the buying interest (Y) consumers of Honda motorcycle dealers Cikarang branch. Based on the conclusion that has been said above, the authors wanted to convey some suggestions that hopefully can be useful and handy so that it can be input to product Pop Honda Beat motorcycle better. The advisement in the mean is a product design, and celebrity endorser has a positive influence on consumer buying interest, means factors that influence the design of the product and celebrity endorser should always be considered and taken into account well and also be adapted and enhanced from the existing conditions at the Honda Beat motorcycle Pop order better future and remains the best-selling motorcycle. Company Astra Honda Motor (AHM) is expected to increase its product design Pop Honda Beat motorcycle that has a different characteristic and also the future issue a more attractive product design to remain better than other motorcycles. It is certainly buying interest impact Honda Beat motorcycle Pop. Company Astra Honda Motor (AHM), especially on a motorcycle Honda Beat Pop is also expected to always consider the advertiser/celebrity endorser in advertising the company's products on television, both in reputation and appeal of the star that is owned by the star. Because it affects the consumer purchase interest in Honda Beat motorcycle products Pop.

\section{References}

[1] Butar, D. K. M. B., \& Wardhana, A, 2016. "Pengaruh Hollywood Celebrity Endorser Terhadap Minat Beli Pada Sepatu Brand Adidas (Studi Kasus Pada Mahasiswa Administrasi Bisnis Angkatan 2016 Kelas A)". Journal Proceedings of Management, Volume3. Nomor 2. ISSN 345-553.

[2] Crilly, N., Moultrie, J., \& Clarkson, P. J, 2004. Seeing things: consumer response to the visual domain in product design. Design studies, 25(6), 547-577.

[3] Erdogan, B. Z, 1999. Celebrity endorsement: A literature review. Journal of marketing management, 15(4), 291-314.

[4] Ferdinand, Augusty, 2012. Metode Penelitian Menejemen. Semarang: Badan Penerbit Universitas Dipenogoro.

[5] Fionda, A. M., \& Moore, C. M, 2009. The anatomy of the luxury fashion brand. Journal of Brand Management, 16(5-6), 347-363. 
[6] Ghozali, Imam, 2013. Aplikasi Analisis Multivarie Dengan program OMB SPSS. Cetakan Keempat. Badan penerbit Universitas Dipenogoro.

[7] Ghoshal, S. 2005. Bad management theories are destroying good management practices. Academy of Management learning \& education, 4(1), 75-91.

[8] Kotler, Philip, and Kevin Lane Keller, 2016. Marketing Management, 15th Edition. New Jersey: Pearson Prentice Hall.

[9] Listyawati, I. H, 2016. Peran Penting Promosi dan Desain Produk dalam Membangun Minat Beli Konsumen. Jurnal Bisnis, Manajemen, dan Akuntansi, 3(1).

[10] McMullan, J. L., \& Miller, D, 2008. All in! The commercial advertising of offshore gambling on television. Journal of Gambling Issues, (22), 230-251.

[11] Oliver, R. L, 1999. Whence consumer loyalty?. The Journal of Marketing, 33-44.

[12] Royan, Frans M, 2012. Marketing Selebrities. Jakarta: Elex Media Komputindo Kelompok Gramedia.

[13] Saidani, Basrah, M. Aulia Rachman, and Mohammad Rizan, 2013. Pengaruh kualitas produk dan desain produk terhadap keputusan pembelian sepatu olahraga futsal adidas di wilayah Jakarta Timur. JRMSI-Jurnal Riset Manajemen Sains Indonesia. Volume 4. nomor 2. ISSN 201-217.

[14] Sudarti, K, 2014. Peran endorser selebriti dalam meningkatkan minat beli konsumen. Dharma Ekonomi, 19(35).

[15] Shocker, A. D., Srivastava, R. K., \& Ruekert, R. W, 1994. Challenges and opportunities facing brand management: An introduction to the special issue. Journal of marketing research, 31(2), 149-158.

[16] Sugiyono, 2012. Statistika Untuk Penelitian. Bandung: Alfabeta.

[17] . 2014. Metode Penelitian Kuantitatif Kualitatif dan R\&D. Bandung: Alfabeta.

[18] Teece, D. J, 2010. Business models, business strategy and innovation. Long range planning, 43(2-3), 172-194.

[19] Padmantyo, S., \& Purnomo, E. 2014. Pengaruh Desain Produk dan Promosi terhadap Volume Penjualan pada Industri Batik (Studi pada Industri Batik di Kabupaten Sragen).

[20] Park, D. H., Lee, J., \& Han, I., 2007. The effect of on-line consumer reviews on consumer purchasing intention: The moderating role of involvement. International journal of electronic commerce, 11(4), 125-148.

[21] Priyanto., W, 2017. Raptor Penjualan Sepeda Motor Honda, Honda Beat terlaris. www.Aishi.com. This article was accessed on February 11, 2018. 20:45.

[22] Wicaksono, M. A, 2018. Pengaruh desain produk dan celebrity endorser terhadap keputusan pembelian honda new sonic 150r (studi pada pengguna honda new sonic 150r di Kota Surabaya). Jurnal ilmu manajemen, Volume 6. Nomor 1.ISSN 876-984 